\title{
Can Theatre-Therapy Increase Creativity and Change Thinking Positively?
}

\author{
Stella Conte \\ Patrizia Puliga \\ Department of Education, Psychology and Philosophy \\ University of Cagliari, Via Is Mirrionis 1 \\ 09123 Cagliari - Sardinia \\ Italy
}

\begin{abstract}
Theater-Therapy, that is Theater (Stanislavksij's Method) joint to Positive Psychology, could improve Creativity aspects positively affecting thinking and self-vision. To test this hypothesis, six subjects took part in a research to ascertain if participation to Theater-therapy increase creativity and change way of thinking. The experiment included one three-hour weekly meeting for six months. On the first day, the TTCT was administered to each subject and re-administered on the last day of the experiment. Every meeting was audio-recorded. The analysis of speech shows that while in the first month of meetings the subjects talked about external events with negative feelings and duties, after six month the subject talked about internal events and affections and the vision of self had changed. Likewise, after six months subjects showed an increase of creativity.
\end{abstract}

Keywords: Theater-therapy, Stanislavskij’s Method, Positive Psychology, Thinking, Creativity, Well-being.

\section{Introduction}

Creativity has been associated to well-being both as un immediate "activator" of positive emotions and as a process of problem-solving that can be generalized to more than one reality (Hennessey and Amabile, 2010). Moreover, positive feeling is associated with creativity and innovative action (Hennessey and Amabile, 2010). Furthermore, creativity plays a primary role in reducing anxiety and depression (Fauladi and Shabidi, 2016). In Theater-therapy, that is the at her (Stanislavskij's method) joint to positive Psychology (Seligman, 1990), the creative process operates simultaneously for every individual involved, as well as for the group. The understanding process is organically synergic (Bicherstaff, 2011). Stress, anxiety and worries are felt in people and cause high in meaningfulness and low in happiness (Seligman, 1990; 2004; 2011). Thus, it could be important to teach them the power of shifting one's perspective in everyday behavior in a positive sense (Seligman, 1990; 2004; 2011).

Theater-therapy based on Positive Psychology approach aims to:

1) increase the experience of positive emotions in participants;

2) develop their own strengths and abilities;

3) find and build a sense of hope into the participants' perspective;

4) help them to find a sense of well-being;

5) help them to find an optimistic point of view.

Moreover, since creativity is crucial to fulfill the abovementioned points (Seligman, 2011), Theater-therapy could be an effective tool to obtain these results. In fact, creativity is the background for problem solving skills. To solve a problem, it is often necessary to change the point of view and leave the old strategy for new challenging solutions (Seligman, 2011).

Moreover, Stanislavksij's method is a very good tool for improving creativity. Stanislavskij $(1936 ; 1938 ; 1950)$ claims that the actor must be freed from his/her personal schemes and, to be credible, he/she must merge with the character he/she plays. Only about one hundred years later, Berne (1967) will talk about personal scripts and freedom of action. To do this, Stanislavskij draws on different artistic experiences and creates a system of physical exercises to transform the body into a tool ready to accept the psychological nuances of the character. 
According to the author, the body is the custodian of the actions corresponding both to emotions and states of mind for the theater workshop. Stanislavskij's method is a system in which emotions are produced through:

1) the use of actions;

2) an analytical research of the given circumstances of the text;

3) imagination (Bussel, 2012).

Hence, these characteristic aspects of Stanislavskij's method show a psychological value because the body is the mean to join emotions. Through the action, the emotions linked to it reappear in all their cognitive and neuroautonomic conditions. Thus, one can learn to get familiar with emotions, to get to know and use them in an adaptive way. Stanislavskij stresses the objectives, which are the character's goals within each scene (Bussel, 2012).Also, this aspect shows a psychological background. Moving with a pre-fixed goal is crucial to recognize the self and for a more internal locus of control. Stanislavskij's Method and Positive Psychology are an effective way to modify the usual point of view and to change thinking positively and full of hope. This current study aims to ascertain if participating in Theater-therapy meetings can increase creativity and change "the ordinary way of seeing things". Specifically, it was studied if Theater-therapy can stimulate to experiment new skills and problem solving involving creativity and thinking. Moreover, a better knowledge of emotions, experienced through physical actions, should improve self-efficacy, positively affecting thinking.

\section{Methods}

\subsection{Subjects}

Five volunteers living in Sardinia (1 male and 4 female) aged $30.3 \pm 3.2$ years.

Education level: master degree for all subjects signed the informed consent for the research.

\subsection{Experimental procedure}

The experiment included one three-hour weekly meeting for six months. Each meeting was divided into two stages. In the first lasting two hours, the subjects were invited to work on body, voice and narration. An improvisation technique was used. In the second stage, lasting one hour, the subjects were requested to give a feedback of their physical, psychological and emotional feelings felt during the first stage. Moreover, they were requested to tell how they were modifying their lives in order to gain a better wellness as well as an effective goal-oriented behavior, according to a Positive Psychology approach (Seligman, 1990, 2004, 2011). All meetings were audio-recorded. All subject had previously signed an informed consent.

\subsection{Torrance Test of Creative Thinking (TTCT)}

This Test aims to assess the individuals capacity for creativity (Torrance, 2000). The TTCT has two version: TTCT - Verbal (forms A and B) and TTCT - Figural (forms A and B). In this research only the TTCT - Figural (form A) was administered. The TTCT- Figural form A consists of three activities: picture construction, picture completion and repeated figures of lines or cicles. Ten minutes are required to complete each activity. In Activity 1 , the subject should construct a picture using shapes (e.g. pear or jellybean) printed on the page. The proposed stimulus must be a part of the final picture (Kim, 2006). Activity 2 asks the subject to make a picture using 10 incomplete figures. Activity 3 is made up of three pages of lines or circles. This stimuli must be a part of the final picture. Torrance (1966) recommended the creation of game situation, avoiding the threatening situation associated with testing.

Four subscale were considered for measuring: Fluency $(\mathrm{F})$ : this ability is measured by the number of releventide as. It is related to the ability to produce a number of figural images from an unique stimulus (Kim, 2016). Originality $(\mathrm{O})$ : it is measured by the number of unfrequentide as. The originality lists have been prepared for each item. The common responses are counted as 1 (Kim, 2016). Elaboration (E): the final score of elaboration comes from the number of addedideas. This skilled monstrates the subject' sability to develop and elaborate an idea (Kim, 2016). Flexibility (Fx): the final score comes from this ability to generate various different ideas using several different strategies. For these subscales raw scores have been converted into standard scores ( $\mathrm{T}$ scores) with mean 50 and standard deviation 10 .

\subsection{Quantitative data analysis}

The quantitative data consist of scores of each subject to TTCT-Figural (Form A) in four subscales: Fluency (F), Originality (O), Elaboration (E), Flexibility (Fx) in two surveys: Test and Retest. 
In order to verify the differences between the Test period and the Retestperiod, as well as to verify changes in the creativity aspects of the subject, a repeated 2x4 ANOVA was performed. Factors were: Time (2 levels: Test and Retest), TTCT (4 levels: F, O, E, Fx).

2.5. Quantitative results

ANOVA 2x4 (repeated design) showed significant results for Times $(F=22.52)$; $\mathrm{df}=1 / 4 ; \mathrm{p}=0.009$; mean of Test $=43.95$; mean of Retest $=53.4)$ (fig.1.). The factor TTCT and interaction Time $\mathrm{x}$ TTCT were not significant $(\mathrm{p}>$ $0.05)$.

The graph shows the mean of TTCT at the test period and the retest period. Graph. 1

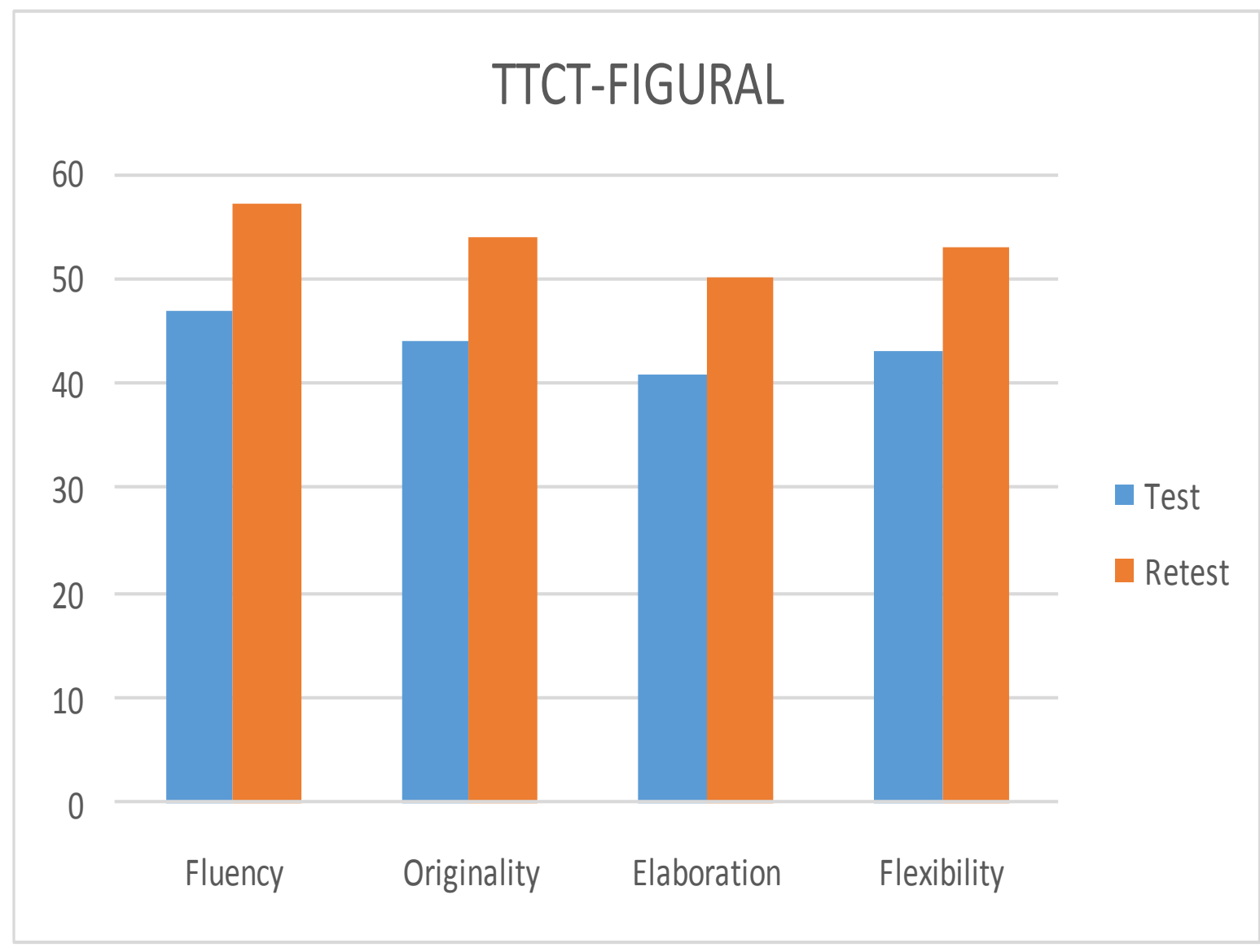

As graph 1 shows, the Theater-terapy meetings improve all aspects of Creativity measured by TTCT. After six months subjects showed a significant increase of fluency, originality, elaboration and flexibility skills.

2.6. Qualitative data analysis

\subsubsection{Text analysis}

For the analysis of the speech the T-lab program was used. T-lab software is an all-in-one set of linguistic and graphical tools for text analysis. The program allows managing tasks such as:

- measure, explore and map the co-occurrence relationship between key-term;

- perform a bottom-up clustering to highlight emerging themes;

- $\quad$ check the lexical units (lemma), context units (sentences) and Themes;

- create a semantic map representing dynamic aspects of the discourse;

- analysis of corpus using key-terms.

\subsection{Qualitative results}

The speech analysis was done in the Italian language. For a better understanding of the results the table 1(in the appendix) with translation from Italian into English of the key-words is reported. Co-occurrence analysis showed changes in the terms of the speechs. Table of key-words Traslated from Italian to English 


\begin{tabular}{|c|c|}
\hline Italian words & English words \\
\hline trovare & find \\
\hline guardare & look \\
\hline rendere & make \\
\hline difficile & difficult \\
\hline esame & exam \\
\hline riuscire & beingable \\
\hline bambino & child \\
\hline conto & account \\
\hline lavoro & work \\
\hline bravo & good \\
\hline obiettivo & goal \\
\hline intelligente & intelligent \\
\hline fatti & facts \\
\hline bello & beautiful \\
\hline problemi & problem \\
\hline studiare & study \\
\hline succedere & succed \\
\hline laureare & graduate \\
\hline persone & people \\
\hline chiedere & ask \\
\hline provare & try \\
\hline amica & friend \\
\hline prendere & take \\
\hline piangere & cry \\
\hline situazione & situation \\
\hline capire & understand \\
\hline sentire & feel \\
\hline pensare & think \\
\hline scegliere & choose \\
\hline cambiare & change \\
\hline preoccupare & worry \\
\hline paura & fear \\
\hline pregare & prey \\
\hline persona & person \\
\hline vedere & see \\
\hline cugino & cousin \\
\hline padre & father \\
\hline ok & ok \\
\hline tranquillo & quiet \\
\hline tipo & kind \\
\hline giorni & days \\
\hline esistere & exist \\
\hline verità & truth \\
\hline gente & people \\
\hline arrivare & get \\
\hline tesi & thesis \\
\hline cercare & look for \\
\hline prima & before \\
\hline
\end{tabular}


In the first month of meetings the subjects talked about external events ("work", "duties," "problems" and so on); in the last month, the contents of speechs were modified and regarded internal events like: "feel", "try", "me", "choose", "think", "understand" and "ok". These words are connected to a greater internal locus of control focused on their lives, with a view "to being ok among so many people ok". To indicate the first period the term "Time 1" was used, and for the last period the term "Time 2" was used. Graph 2 shows the association between words with "Time 1". Graph. 3 shows the association between words with "Time 2".

The graph reports the results of the co-occurrence analysis between words and Time 1 .

Graph 2

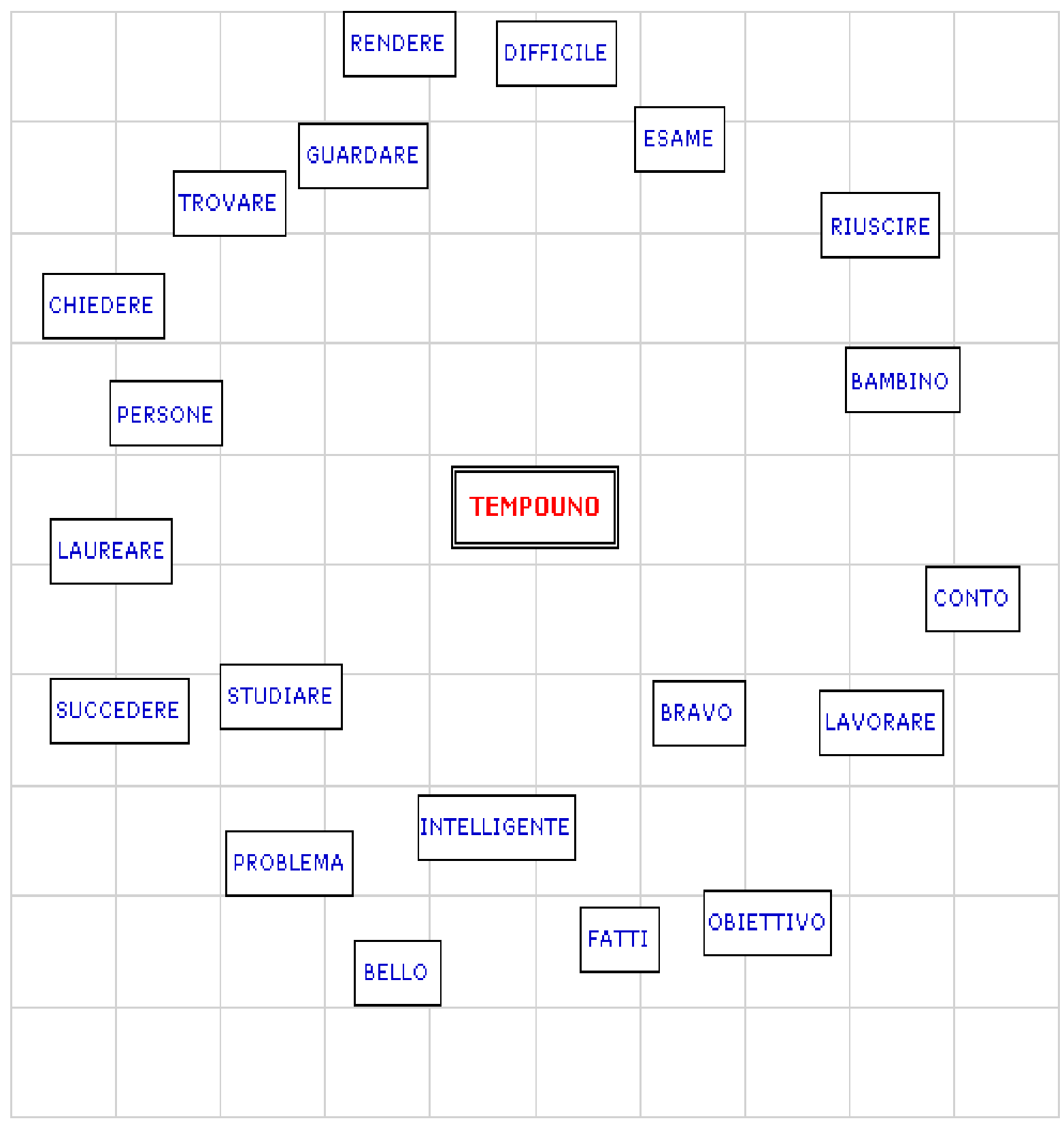

The graphre presents the results of the co-occurrence analysis between word and Time 2 . 


\section{Graph 3}

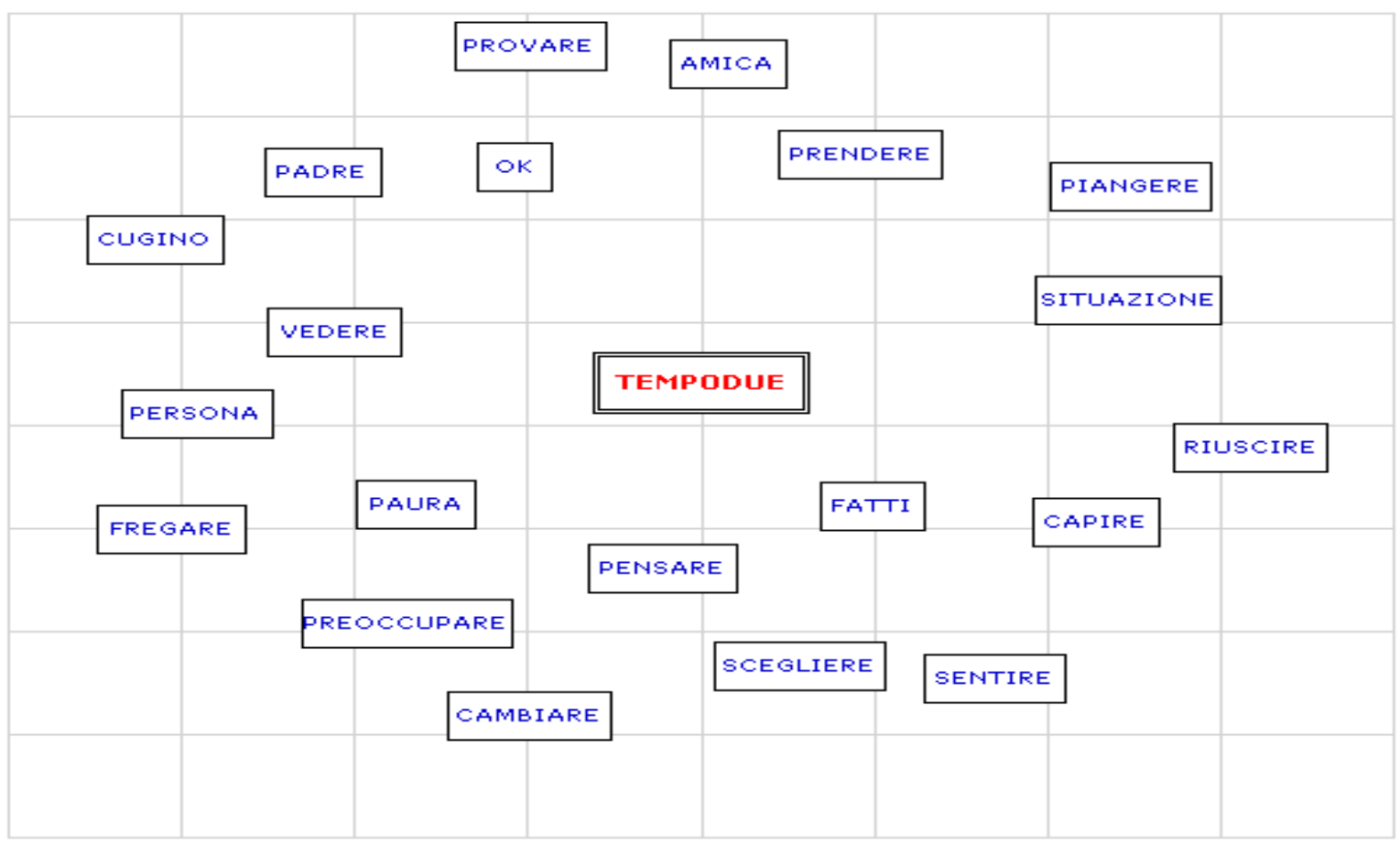

The words associated with "Time 1" were related to the working life or study (i.e. external situations). (Graph. 3). The word associated with "Time 2" were different from the previously mentione dones. Infact, these were words related to internal world and affective words ("choose", "feel", friend") (Graph. 4). Results for co-occorrence between couples of key-words. Were reported in Graph. 4 and Graph. 5. The shared associations between lemma "anxiety" ("ansia" in the italian language) and "Time 1" with other words werere ported in graph. 4. The graph shows the associations between lemma "anxiety", "Time 1" and other words.

\section{Graph 4}

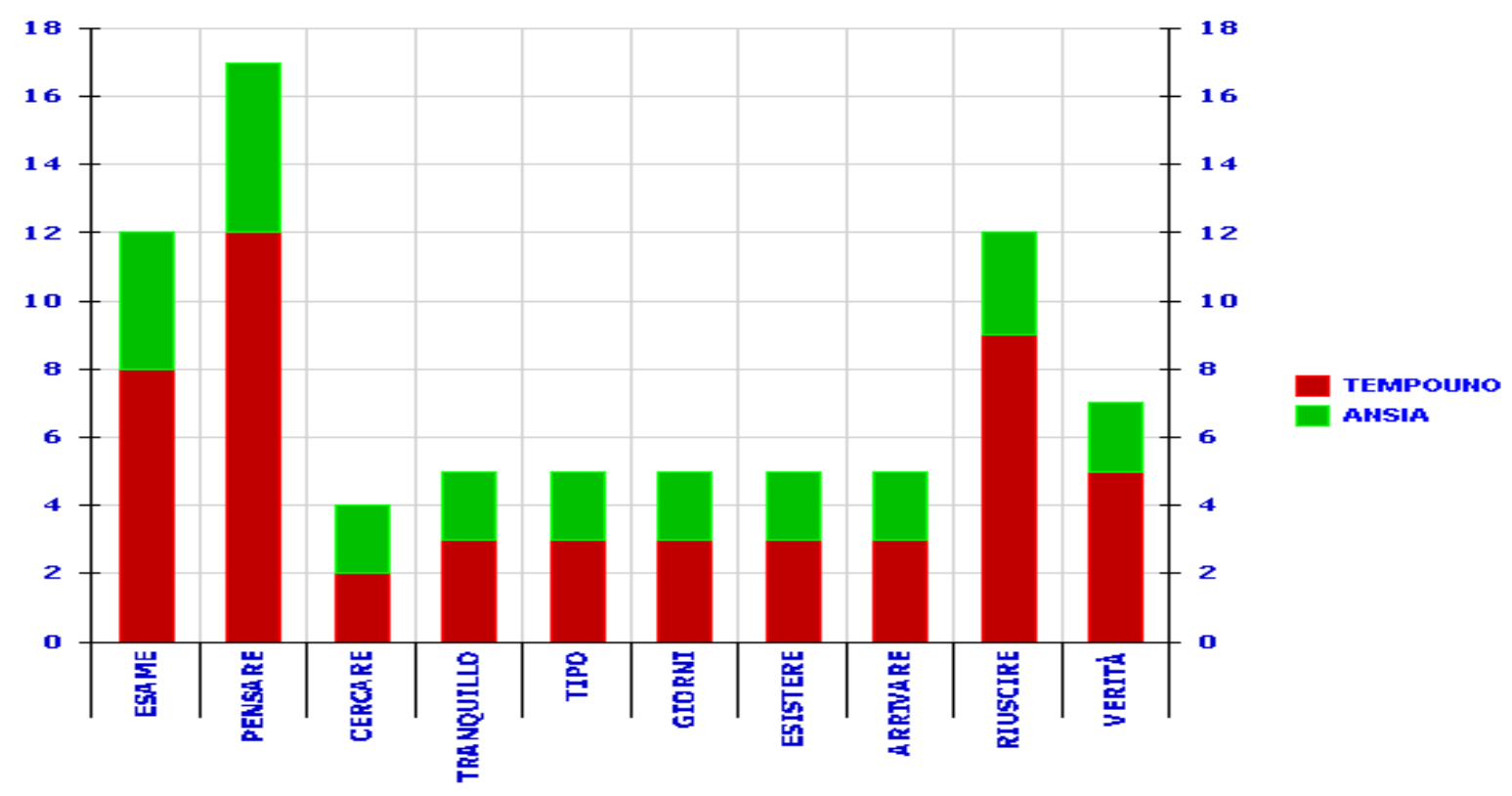

The shared associations between lemma "anxiety", "Time 2" and other words are reported in Graph. 5. The graph presents the associations between lemma "anxiety", "Time 2" and other words. 
Graph. 5

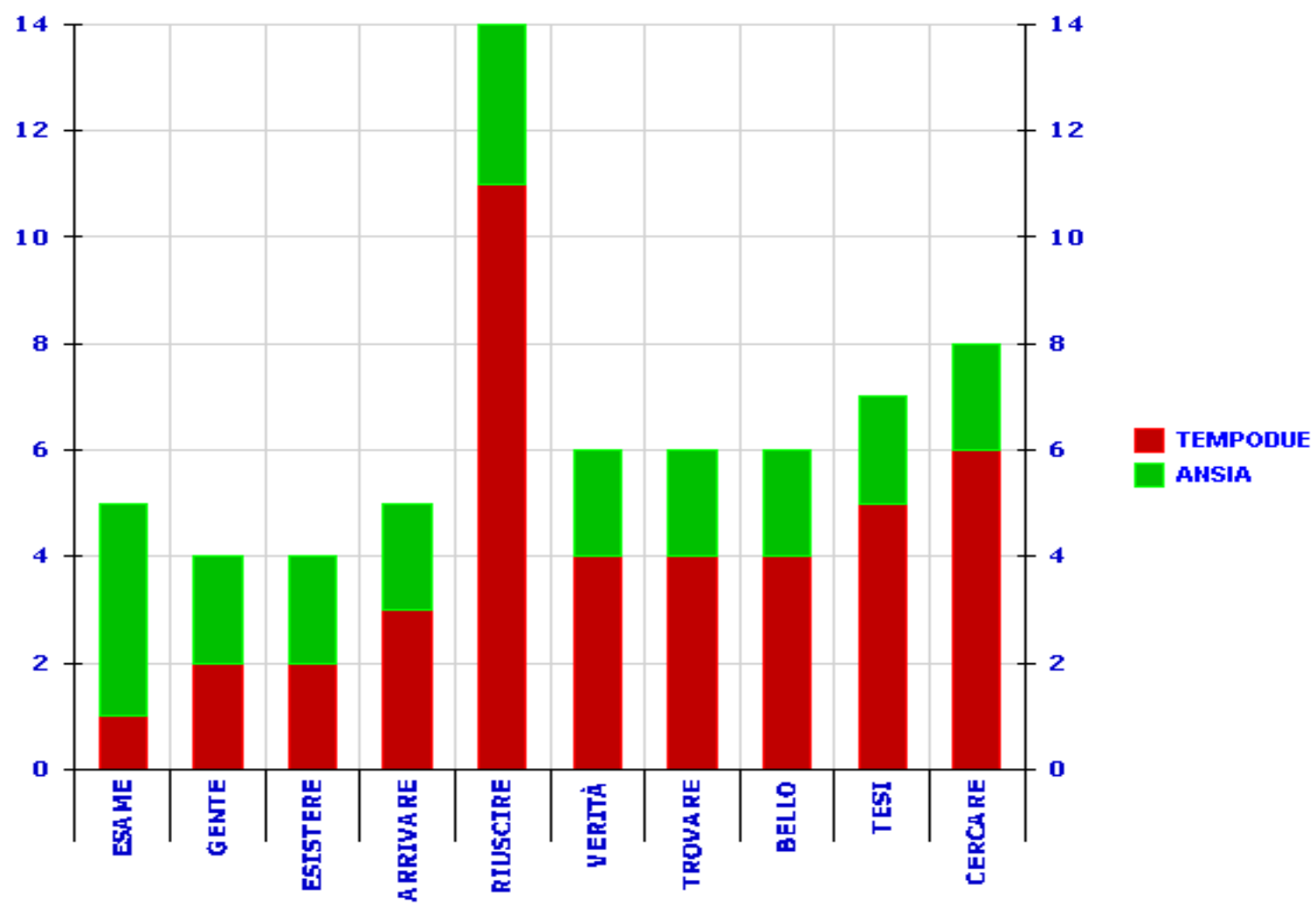

As can be seen from the graphs, the word "examination" is present at "Time 1" with a very high value, while the same has a much lower value at "Time 2". In contrast, the word "to be able" is present at "Time 1" with a low value, while the same word has a much higher value at "Time 2". The power of relactions between words is very different among Time 1 and Time 2.

\section{Discussion}

Theater-therapy, that is Theater (Stanislavksij's Method) joint to Positive Psychology, could improve creativity aspects that positively affect thinking and self-vision. In fact, the current study shows a significant increase of creativity (TTCT) between the beginning and the end of Theater-therapy. This means that Theater-therapy is useful for changing creativity aspects and increase problem solving skills. Joining Stanislavskij's method (Stanislavskij 1936,1938,1950) with Positive Psychology (Seligman, 1990, 2004, 2011) is useful for: increasing experience of positive emotion, a better development of their own abilities, building a sense of hope and wellbeing and, reaching a view "to being ok among so many people ok". These aspects affect the individual thought and goals. In fact, the participants learnt to trust the other and tend to be sensitive towards their own and the other is needs. This implies a greater acceptation of self and the other and a greater openness towards the experience of life. In fact, the speech analysis shows that while in the first month of meetings the subjects talked about external events with negative feelings and duties, after six month the subject talked about internal events and affections with a positively changed vision of self. The person is the center of his/her inner world and lives himself/herself as "ok". The thought "I'm able" becomes the centre of the speeches of the last period.

\section{References}

Berne, E., (1967). Games People Play:the Psychology of Human Relations. New York: Grove Press.

Bickerstaff, J.(2011). Collaborative theatre/creative process. Communication and Theater Association of Minnesota Journal, 38,42-54.

Bussel, K., (2012).Acting in Opera: A Stanislavsky Approach undergraduate Honor theses. East Tennessee State University. https://dc.etsu.edu/honors/52. 
Fouladi, N., \& Shahidi, E.(2016). Creativity, Thinking style and Mental Disorders. Journal of Fundamental and Applied Sciences, 8, 1728-1736.

Hennessey, B., \& Amabile, T.(2010). Creativity. Annual Review Psychology, 61,569-598.

Kim, K.H. (2006). Can We Trust CreativityTests? A Review of the Torrance Tests of Creative Thinking (TTCT). Creativity Research Journal, 18, 1, 3-14. doi: 10.1207/s15326934crj1801_2.

Kim, K. H. (2016). The creativity challenge: How we can recapture American innovation. Amherst, NY: Prometheus Books.

Seligman, M.E.P.(1990). Learning optimism. New York: Vintage Book.

Seligman, M. E. P.(2004). Authentic happiness. London: Brealy.

Seligman, M. E. P.(2011). Flourish: a visionary new understanding of happiness and well-being. New York: Free Press.

Stanislavskij, K.(1936). An actor Prepares. London: Methuen, 1988.

Stanislavskij, K.(1938).An Actor's Work: A Student's Diary. London-New-York: Routledge, 2008.

Stanislavskij, K., (1950). Stanislavsky on the art of the stage. London: Faber, 2002.

Torrance, E. P. (1966). The Torrance Tests of Creative Thinking-Norms-Technical Manual Research EditionVerbal Tests, Forms A and B-Figural Tests, Forms A and B. Princeton, NJ: Personnel Press.

Torrance, E. P. (2000). Research review for the Torrance Tests of Creative Thinking Figural and Verbal forms A and B. Bensenville, IL: Scholastic Testing Services.

Watson, D., \&TellegenA. (1985). Toward a consensual structure of mood”. Psychological Bulletin, 98, 219 - 235. 